\title{
DISKRIMINATIF GENDER DALAM LINGKUNGAN KERJA
}

\author{
Zainul Akbar ${ }^{1}$, Haryanti Arifudding ${ }^{2}$, Wulandari, Viky Ade Satria ${ }^{4}$ \\ Sekolah Tinggi Ilmu Hukum amsir Parepare \\ Jl. Andi Sapada No.11, Sumpang Minangae, \\ Kec. Bacukiki Bar., Kota Parepare, \\ Sulawesi Selatan 91121 \\ zainulinul560@gmail.com, hariyantiarifuddling@gmail.com, \\ wulandarisyam361@gmail.com, padiiap01@ gmail.com
}

\begin{abstract}
Gender is the differentiation of roles, functions and responsibilities between women and men resulting from socio-cultural construction and can change according to the times. This paper discusses the main issues of gender in the perspective of human rights and gender equality education in Indonesia. Gender is a gender difference that is not caused by biological differences and not God's nature, but was created by both men and women through a long sociocultural process. There's several factors influencing that inequality, include marginalization to women, on public or domestic domain. Woman subordination in social or cultural aspect also affects discrimination. Labeling (stereotyping) to women and lower education level also affect woman work participation. As a consequence, many women choose work activity at informal environment with very low wages and without health, law, and financial security
\end{abstract}

Keyword: Discrimination, Gender, woman, occupation.

\section{Latar Belakang Masalah}

Keadilan dalam kehidupan masyarakat seharusnya dapat dinikmati oleh seluruh elemen masyarakat tampa mengenal status, jabatan, ras,suku, dan jenis kelamin, sehingga tercipta kehidupan sosial yang adil dan makmur tanpa adanya diskriminasi, namun realitas sosial yang terjadi, ternyata masih banyak ketidakadilan yang terjadi dalam masyarakat termasuk dalam ketidakadilan yang membedakan jenis kelamin antar lakilaki dan perempuan (biologis) (Kemenpppa, 2018). Ketidakadilan dan diskriminasi itu terjadi hampir di semua bidang, mulai dari yang terendah hingga pada level internasional. Diskriminasi pun juga terjadi dalam berbagai bidang kehidupan sosial seperti ekonomi, politik, agama, pendidikan dan budaya bahkan sampai tingkatan wilayah kerja.

Diskriminasi adalah suatu bentuk sikap dan perilaku yang melanggar hak asasi manusia (Ihromi, 2007). Diskriminasi juga dapat diartikan sebagai perlakuan 
terhadap individu secara berbeda dengan didasari faktor ras, agama, gender. Setiap pelecehan, pembatasan, atau pengucilan terhadap ras, agama, ataupun gender termasuk tindakan yang diskriminatif. Diskriminasi terhadap perempuan adalah melanggar hak asasi perempuan. Rekomendasi No.19 sidang ke 11 Komite 1992, tentang kekerasan terhadap wanita yang terdapat pada Undangundang menyatakan bahwa diskriminasi meliputi kekerasan berdasarkan jenis kelamin yaitu kekerasan yang ditujukan kepada wanita karena dia adalah seorang wanita atau mempunyai pengaruh secara tidak sepadan pada wanita (Ihromi, 2007). Adapun diskriminasi gender adalah sebuah ketidakadilan dengan pembedaan sikap dan perlakuan terhadap sesama manusia berdasarkan jenis kelamin.

Sejarah kesetaraan gender dan keadilan gender ini tidak muncul begitu saja, dilatar belakangi dengan adanya bentuk ketidakadilan gender yang dilakukan oleh kaum laki-laki terhadap kaum perempuan sehingga ada sosok perempuan hebat yang ingin memperjuangkan hak persamaan kedudukan antara laki-laki dan perempuan yaitu RA Kartini. Adapun tujuan dari RA Kartini dalam memperjuangkan kesetaraan gender dan keadilan gender yaitu untuk menyamaratakan kedudukan antara laki-laki dan perempuan khususnya dalam bidang menempuh pendidikan (Rahniawati, 2001). Hal ini tersirat dalam Pasal 27 Undang-Undang Dasar 1945 akan tetapi realisasi pengakuan itu belum sepenuhnya terlaksana dalam berbagai bidang kehidupanPerjuangan RA Kartini untuk persamaan hak dan kedudukan antara laki-laki dan perempuan ini dimulai dalam bidang pendidikan. Sebagai bentuk perjuangannya, beliau mendirikan sekolah untuk kaum perempuan sebagai wujud untuk melawan ketidakadilan gender dan diskriminasi yang didapatkan oleh kaum perempuan sejak saat itu (Amar, 2017).

Selama satu dekade terakhir, partisipasi perempuan di pasar tenaga kerja mengalami peningkatan yang cukup nyata, meskipun prosentasenya kecil jika dibandingkan dengan laki-laki. Perubahan ini menunjukkan adanya peningkatan peran perempuan yang sangat berarti dalam kegiatan ekonomi di Indonesia. Namun demikian, struktur angkatan kerja perempuan memiliki tingkat pendidikan yang rendah. Dengan demikian, sebagian besar perempuan masih berkiprah di sektor informal atau pekerjaan yang tidak memerlukan kualitas pengetahuan dan keterampilan canggih atau spesifik. Dalam perspektif gender, proporsi tenaga 
kerja perempuan dan laki-laki di sektor informal adalah $40 \%$ perempuan, dan $60 \%$ laki-laki. Proporsi tenaga kerja perempuan di sektor informal ini mencakup 70\% dari keseluruhan tenaga kerja perempuan (Murti dan Krisni, 2005).

Pekerjaan perempuan di sektor informal biasanya kurang memberikan jaminan perlindungan secara hukum dan jaminan kesejahteraan yang memadai, di samping kondisi kerja yang memprihatinkan serta pendapatan yang rendah. Namun demikian, meski perempuan mendapat upah hanya $70 \%$ dibandingkan laki-laki, tetapi perempuan telah mengambil porsi $45 \%$ dari seluruh partisipasi angkatan kerja. Dalam area pertanian, perempuan mengalami porsi $48,65 \%$, perdagangan perempuan mengambil porsi $23,44 \%$. Sementara dalam area industri, tenaga kerja perempuan meliputi $13,44 \%$ dan jasa $12,24 \%$. Pada aspek pertanian, di mana kebanyakan kaum perempuan menjadi tenaga kerja tanpa upah karena merupakan usaha keluarga sebanyak $80 \%$. Dari data tersebut, dapat dilihat betapa perempuan kurang mendapat akses dan keadilan dalam bidang ekonomi. Perempuan masih banyak melakukan pekerjaan di sektor informal yang tidak memerlukan keahlian dan keterampilan, dan tentunya ini berimplikasi pada perlindungan hukum yang kurang, penerimaan upah yang tidak memadai, belum lagi beban ganda yang dirasakan (Abdullah, 1990).

Berdasarkan latar belakang tersebut maka pada penulisan kali ini akan membahas mengenai hakikat kesetaraan gender di Indonesia, Peran pemerintah dalam penegakan kesetaraan gender di Indonesia, diskriminasi gender terhadap perempuan dalam sektor pekerjaan yang mencakup pembagian kerja dalam lintasan sejarah, faktor-faktor yang menyebabkan diskriminasi, serta kaitannya dengan kesetaraan dan keadilan.

\section{Metode Penelitian}

Metode penelitian yang digunakan dalam penyusunan jurnal ini yaitu menggunakan metode penelitian normatif. Penelitian Hukum Normatifmerupakan penelitian hukum yang dilakukan dengan cara meneliti bahan pustaka atau data sekunder.Penelitian hukum normatif disebutjuga penelitian hukumdoktrinal. Penelitian yang dilakukan bersifat deskriptif analitis yaitu menggambarkan, menganalisis, menyimpulkan masalah-masalah yang menjadi objek penelitian.(Syahruddin Nawi,2017:7) 


\section{Analisis dan Pembahasan}

- Hakikat Kesetaraan Gender di Indonesia

Gender merupakan aspek hubungan sosial yang dikaitkan dengan diferensiasi seksual pada manusia (Demartoto, 2007). Istilah "gender" yang berasal dari bahasa Inggris yang di dalam kamus tidak secara jelas dibedakan pengertian kata sex dan gender. Untuk memahami konsep gender, perlu dibedakan antara kata sex dan kata gender. Sex adalah perbedaan jenis kelamin secara biologis sedangkan gender perbedaan jenis kelamin berdasarkan konstruksi sosial atau konstruksi masyarakat. Dalam kaitan dengan pengertian gender ini, Astiti mengemukakan bahwa gender adalah hubungan laki-laki dan perempuan secara sosial. Hubungan sosial antara lakilaki dan perempuan dalam pergaulan hidup sehari-hari, dibentuk dan dirubah (Fibrianto dan Bakhri, 2018).

Secara umum, pengertian Gender adalah perbedaan yang tampak antara laki-laki dan perempuan apabila dilihat dari nilai dan tingkah laku. Dalam Women Studies Ensiklopedia dijelaskan bahwa Gender adalah suatu konsep kultural, berupaya membuat perbedaan (distinction) dalam hal peran, perilaku, mentalitas, dan karakteristik emosional antara laki-laki dan perempuan yang berkembang dalam masyarakat (Vitalaya, 1998). Gender adalah perbedaan yang tampak pada laki-laki dan perempuan apabila dilihat dari nilai dan tingkah laku. Gender merupakan suatu istilah yang digunakan untuk menggambarkan perbedaan antara laki-laki dan perempuan secara social (Andrey, 2014). Sedangkan Heddy Shri Ahimsha Putra (2000)mengemukakan bahwa gender adalah kelompok atribut dan perilaku secara kultural yang ada pada laki-laki dan perempuan.

Dengan demikian gender sebagai suatu konsep merupakan hasil pemikiran manusia atau rekayasa manusia, dibentuk oleh masyarakat sehingga bersifat dinamis dapat berbeda karena perbedaan adat istiadat, budaya, agama, sitem nilai dari bangsa, masyarakat, dan suku bangsa tertentu. Selain itu gender dapat berubah karena perjalanan sejarah, perubahan politik, ekonomi, sosial dan budaya, atau karena kemajuan pembangunan. Dengan demikian gender tidak bersifat universal dan tidak berlaku secara umum, akan tetapi bersifat situasional masyarakatnya (Fibrianto dan Bakhri, 2018). 
Salah satu sendi utama dalam demokrasi yaitu Kesetaraan Gender karena menjamin bebasnya untuk berpeluang dan mengakses bagi seluruh elemen masyarakat. Gagalnya dalam mencapai cita-cita demokrasi, seringkali dipicu oleh ketidaksetaraan dan ketidakadilan gender. Ketidaksetaraan ini dapat berupa diskriminatif yang dilakukan oleh merekayang dominan baik secara struktural maupun kultural (Dzuhayatin dan siti, 2007). Perlakuan diskriminatif dan ketidaksetaraan dapat menimbulkan kerugian dan menurunkan kesejahteraan hidup bagi pihak-pihak yang termarginalisasi dan tersubordinasi. Sampai saat ini diskriminasi berbasis pada gender masih terasakan hampir di seluruh dunia, termasuk di negara di mana demokrasi telah dianggap tercapai. Dalam konteks ini, kaum perempuan yang paling berpotensi mendapatkan perlakuan yang diskriminatif, meski tidak menutup kemungkinan laki-laki juga dapat mengalaminya. Pembakuan peran dalam suatu masyarakat merupakan kendala yang paling utama dalam proses perubahan sosial. Sejauh menyangkut persoalan gender di mana secara global kaum perempuan yang lebih berpotensi merasakan dampak negatifnya (Mukherjee, 2002).

Kesetaraan Gender merupakan kesamaan kondisi bagi laki-laki dan perempuan untuk memperoleh kesempatan serta hak-haknya sebagai manusia, agar mampu berperan dan berpartisipasi dalam kegiatan politik, hukum, ekonomi, sosial budaya, pendidikan dan pertahanan dan keamanan nasional (hankamnas), serta kesamaan dalam menikmati hasil pembangunan tersebut (UUD 1945 beserta amandemennya). Kesetaraan gender juga meliputi penghapusan diskriminasi dan ketidakadilan struktural, baik terhadap laki-laki maupun perempuan. Kesetaraan gender memiliki kaitan dengan keadilan gender. keadilan gender merupakan suatu proses dan perlakuan adil terhadap laki-laki dan perempuan. terwujudnya kesetaraan dan keadilan gender ditandai dengan tidak adanya diskriminasi baik terhadap laki-laki maupun perempuan (Asgar, 1994).

Kemajuan ekonomi dan globalisasi membuat pasar kerja semakin kompleks. Dampak lain dari kemajuan tersebut, terlihat dari makin membaiknya status serta lowongan kerja bagi wanita. Walaupun angka partisipasi angkatan kerja wanita meningkat, namun tidak sedikit wanita yang bekerja penggal waktu atau bekerja di sektor informal. Hal ini berkaitan dengan peran-peran ganda wanita sebagai ibu yang bertanggung jawab atas 
urusan rumah tangga termasuk membesarkan anak, serta sebagai pekerja perempuan. Partisipasi wanita saat ini bukan sekedar menuntut persamaan hak, tetapi juga menyatakan fungsinya mempunyai arti bagi pembangunan dalam masyarakat Indonesia. Partisipasi wanita menyangkut peran tradisi dan peran transisi, peran tradisi atau domestik mencakup peran wanita sebagai istri, ibu dan pengelola rumah tangga (Dzuhayatin dan siti, 2007).

Memperhatikan peranan wanita dalam pembangunan, sejak sensus 1971 sudah mulai dirasakan kesenjangan partisipasi dalam pembangunan antara pria dan wanita. Kaum wanita mengalami diskriminasi tidak saja di sektor domestik, sektor publik kaum wanita mengalami hal yang sama. Sistem ekonomi industri yang kapitalik yang mengutamakan pertumbuhan dan konsumsi justru menimbulkan diskriminasi terhadap wanita. Diskriminasi di bidang ekonomi dapat dilihat dari kesenjangan upah yang diterima wanita dibanding pria. Kesenjangan ini bisa dilihat pada setiap kategori seperti tingkat pendidikan, jam kerja, dan lapangan usaha. Semakin rendah tingkat pendidikan wanita, semakin besar besar kesenjangan upah yang diterima terhadap pria (Cleves dan Julia, 2002).

Rendahnya tingkat pendidikan wanita ini akan berdampak pada kedudukan mereka dalam pekerjaan dan upah yang mereka terima. Hal serupa juga terjadi pada jenis usaha, artinya wanita yang melakukan usaha ekonomi yang sama dengan pria mendapatkan penghasilan yang lebih rendah (Fakih, 1999). Ketertinggalan wanita pada peran transisi mereka adalah apabila ditelusuri lebih lanjut kelihatannya berpangkal pada pembagian pekerjaan secara seksual di dalam masyarakat di mana peran wanita yang utama adalah lingkungan rumah tangga dan peran pria yang utama di luar rumah sebagai pencari nafkah utama. Pembagian kerja secara seksual ini jelas tidak adil bagi wanita, sebab pembagian kerja seperti ini selain mengurung wanita juga menempatkan wanita pada kedudukan subordinat terhadap pria, sehingga cita-cita untuk mewujudkan wanita sebagai mitra sejajar pria, baik dalam keluarga maupun dalam masyarakat mungkin akan sulit terlaksana (Darahim, 2003).

Hak-hak perempuan harusnya sama dengan hak-hak dengan laki-laki, contohnya di dalam putusan Nomor 89/PUU-XII/2014 menyatakan bahwa Pasal 97 ayat (2), Undang-Undang Nomor 17 Tahun 2014 tentang Majelis Permusyawaratan Rakyat, Dewan Perwakilan Rakyat, Dewan Perwakilan 
Daerah, Dan Dewan Perwakilan Rakyat Daerah UndangUndang Dasar 1945, sepanjang tidak dimaknai Pimpinan komisi terdiri atas 1 (satu) orang ketua dan paling banyak 3 (tiga) orang wakil ketua dan sekurang-kurangnya $30 \%$ keterwakilan perempuan, yang dipilih dari dan oleh anggota komisi dalam satu paket yang bersifat tetap berdasarkan usulan fraksi sesuai dengan prinsip musyawarah untuk mufakat.

- Peran pemerintah dalam penegakan kesetaraan gender di Indonesia

Diskriminasi terhadap perempuan dalam hal kesetaraan gender sangat bertentangan dengan nilai-nilai hak asasi manusia, Sebagai salah satu upaya untuk meminimalisasi terjadinya diskriminasi, Indonesia telah meratifikasi Konvensi tentang Penghapusan Segala Bentuk Diskriminasi terhadap Perempuan (CEDAW) melalui Undang-Undang Nomor 7 Tahun 1984 dan Konvensi tentang Hak-Hak Anak (CRC) melalui Keputusan Presiden Nomor 36 Tahun 1990.

Pada dasarnya, Konvensi ini menekankan prinsip kesetaraan (equality) dan keadilan (justice) antara perempuan dan laki-laki, yaitu persamaan hak dan kesempatan serta perlakuan di segala bidang kehidupan dan segala kegiatan kesamaan di semua sektor, tetapi kesetaraan perlakuan dan kesempatan dalam dunia politik, ekonomi, sosial, dan lain-lain (Rahayu, 2015). Di samping itu, Konvensi ini juga mengakui beberapa hal, antara lain Terdapat perbedaan biologis atau kodrati antara perempuan dan lakilaki. Perbedaan tersebut mengakibatkan adanya perbedaan perlakuan yang berbasis gender yang mengakibatkan kerugian pada perempuan. UndangUndang Nomor 7 Tahun 1984 tentang Pengesahan Konvensi Mengenai Penghapusan Segala Bentuk Diskriminasi Terhadap Wanita (Convention On The Elimination Of All Forms Of Discrimination Against Women) ini mengakui adanya kerugian antara lain berupa subordinasi pembatasan kemampuan dan kesempatan dalam memanfaatkan peluang yang ada; Peluang itu dapat berupa peluang untuk pembangunan. Selain itu terdapat perbedaan kondisi dan posisi antara perempuan dan lakilaki, dimana perempuan ada dalam kondisi dan posisi yang lemah karena mengalami diskriminasi atau menanggung akibat karena perlakuan diskriminatif atau karena lingkungan, keluarga, dan masyarakat tidak mendukung kemandirian perempuan (Ayu dan Novia, 2020). 
Disahkannya RUU Kewarganegaraan Republik Indonesia oleh DPR tanggal 11 Juli 2006 yang menggantikan Undang-Undang Nomor 62 Tahun 1958 tentang Kewarganegaraan Republik Indonesia menjadi Undang-Undang Nomor 12 Tahun 2006, telah memberikan kontribusi dalam upaya menghapuskan tindakan diskriminatif terhadap perempuan dan anak dan kaum etnis serta telah mengakomodasikan berbagai kepentingan yang mendukung penghapusan diskriminasi dalam berbagai bentuk. Undangundang tersebut antara lain berisi ketentuan untuk melindungi perempuan yang menikah dengan pria berkebangsaan asing, tidak secara otomatis status kewarganegaraan perempuan serta anak yang dilahirkan menjadi warga negara asing (Ayu dan Novia, 2020).

Upaya memberikan perlindungan terhadap anak telah dilakukan dengan diundangkannya Undang-Undang Nomor 23 Tahun 2002 tentang Perlindungan Anak yang antara lain mengatur tentang pengurusan akte kelahiran anak yang bebas biaya. Namun pada pelaksanaannya ketentuan ini belum sepenuhnya dapat dijalankan di beberapa daerah. Hal ini antara lain disebabkan belum adanya komitmen yang maksimal dari aparat penyelenggara negara dalam menjalankan ketentuan undang-undang secara konsisten dalam rangka mengakomodasi kepentingan dan hak anak (Ayu dan Novia, 2020). Untuk mendukung pelaksanaan Undang-Undang Nomor 39 Tahun 2004 tentang Penempatan dan Perlindungan Tenaga Kerja Indonesia di Luar Negeri dan dalam rangka perlindungan terhadap ketenagakerjaan terutama terhadap tenaga kerja perempuan yang bekerja di luar negeri yang rawan terhadap praktek diskriminasi, saat ini sedang dilakukan peta permasalahan TKI perempuan dikaitkan dengan kebijakan ketenagakerjaan berupa Equal Employment Opportunity (EEO).

Dalam rangka penghapusan kekerasan dalam rumah tangga, telah disahkan Undang-Undang Nomor 23 Tahun 2004 tentang Penghapusan Kekerasan dalam Rumah Tangga. Sebagai tindak lanjut dari undangundang tersebut telah dikeluarkan Peraturan Pemerintah Nomor 4 Tahun 2006 tentang Penyelenggaraan dan Kerjasama Pemulihan Korban Kekerasan dalam Rumah Tangga yang telah ditetapkan pada tanggal 13 Februari 2006. Selain itu saat ini tengah dibahas perubahan RUU KUHAP yang mengupayakan untuk mengintegrasikan konsep sistem peradilan pidana 
terpadu antara aparat penegak hukum khususnya bagi penanganan kasus kekerasan terhadap perempuan (Ayu dan Novia, 2020).

\section{- Pembagian kerja dalam lintasan sejarah}

Dalam lintasan sejarah, setiap kelompok masyarakat mempunyai konsepsi ideologis tentang jenis kelamin. Di beberapa kelompok masyarakat, jenis kelamin digunakan sebagai kriteria yang penting dalam pembagian kerja. Kelompok-kelompok masyarakat tersebut membagi peran, tugas dan kerja berdasarkan jenis kelamin, meskipun sebagaian di antaranya ada yang dipandang cocok dan wajar untuk dilakukan oleh kedua jenis kedua jenis kelamin (Saptari dan Bridgett, 1997).

Pekerjaan yang diperuntukkan bagi laki-laki umumnya yang dianggap sesuai dengan kapasitas biologis, psikologis, dan sosial sebagai laki-laki, yang secara umum dikonsepsikan sebagai orang yang memiliki otot lebih kuat, tingkat resiko dan bahayanya lebih tinggi karena bekerja di luar rumah, dan tingkat keterampilan dan kerjasamanya lebih tinggi Adapun pekerjaan yang diperuntukkan bagi perempuan yang dikonsepsikan sebagai orang yang lemah dengan tingkat resiko lebih rendah, cenderung bersifat mengulang, tidak memerlukan konsentrasi, dan lebih mudah terputus-putus. Oleh karena itu, tingkat keterampilan perempuan dianggap rata-rata lebih rendah di banding laki-laki (Vitalaya, 1998).

Menurut penelitian George Peter Murdock, laki-laki lebih konsisten kepada pekerjaan maskulin yaitu memburu binatang, mengerjakan logam, melebur biji-biji, pekerjaan soldir, pertukangan kayu, membuat instrumen musik, menangkap dengan perangkap, membuat kapal, pertukangan batu, mengerjakan tulang-tulang, tanduk dan kulit kering, menambang, dan mengangkut. Perempuan lebih konsisten kepada pekerjaan feminin, yaitu mengumpulkan bahan bakar (kayu), mempersiapkan minuman, meramu dan menyediakan bahan makanan dari tumbuhan-tumbuhan liar, produksi bahan susu, mencuci, mengambil air dan memasak, dan pekerjaan rumah tangga lainnya (Saptari dan Bridgett, 1997).

Dalam masyarakat industri, pola pembagian kerja belum banyak berbeda dengan masyarakat agraris. Dalam masyarakat industri kaum perempuan diupayakan untuk terlibat di dalam kegiatan ekonomi, namun masih banyak warisan agraris dipertahankan di dalamnya. Secara umum 
substansi pola publik domestik masih dipertahankan, karena partisipasi perempuan masih dihargai lebih rendah daripada laki-laki. Lagipula, perempuan masih lebih umum dialokasikan pada bidang-bidang tertentu seperti pekerjaan tulis-menulis, kesekretariatan, jasa, dan yang berhubungan dengan kegiatan pengasuhan dan perawatan seperti guru, perawat. Masih sangat sedikit perempuan yang masuk di dalam lingkaran profesional dan eksekutif. Laki-laki masih tetap dominan di sektor profesi yang memiliki status lebih tinggi, seperti teknik, arsitek, dokter, kontraktor, manajer, dan lain sebagainya. Laki-laki mendominasi industri hulu yang produktivitasnya lebih tinggi, sementara perempuan terlibat dalam industru hilir, yang menangani proses akhir dari sebuah produk (finishing), yang upah produktivitasnya lebih rendah. Tegasnya, dalam masyarakat industri, pembagian kerja secara seksual, cenderung dipertahankan. Pola relasi masih berlangsung tidak seimbang, dan dengan demikian status dan kedudukan perempuan masih lemah (Patimah, 2009).

Adapun pembagian kerja berdasarkan gender dapat berubah-ubah. Pembagian kerja berdasarkan gender merupakan cara efisien untuk menjamin kelangsungan hidup unit keluarga dan beradaptasi dengan lingkungan tertentu. Pada pembagian kerja ini, kerja perempuan tidak sematamata menyatakan tingkat status. Kerja perempuan bisa jadi dilihat sebagai hal yang sama-sama bernilai dengan laki-laki, walaupun ada juga di banyak masyarakat petani pembagian kerja melibatkan tingkat signifikansi sepanjang garis-garis gender. Dengan adanya risiko penggeneralisasian, tampak bahwa ketika perekonomian uang diperkenalkan, keseimbangan antara tenaga kerja perempuan dan laki-laki mulai berubah.Yang pasti, hukum kolonial setidaknya telah mengubah hubungan gender menjadi ketidakadilan gender. Kolonialisme ini memiliki peran dalam masyarakat sebagai model, dan karenanya berasumsi bahwa perempuan seharusnya tidak bekerja untuk mendapatkan upah (Darahim, 2003).

Dari penggambaran di atas, dapat disimpulkan bahwa diskriminasi gender dalam pekerjaan telah berlangsung lama, baik dalam masyarakat agraris maupun masyarakat industri, baik dilihat pada pembagian kerja berdasarkan jenis kelamin maupun berdasarkan gender. Walaupun posisi perempuan memiliki kontribusi yang cukup besar dalam pekerjaan, akan tetapi karena budaya patriarkhi yang berkembang di masyarakat, sehingga 
menempatkan pekerjaan perempuan yang tidak seimbang dengan laki-laki, dan masih dinilai sebagai pekerjaan yang tidak produktif.

Sejak zaman dahulu ketika manusia masih mencari penghidupan dengan cara berburu dan meramu, seorang istri sesungguhnya sudah bekerja ketika suaminya pergi berburu. Di rumah, istri bekerja menyiapkan makanan dan mengelola hasil buruan untuk ditukarkan dengan bahan lain yang dapat dikonsumsi keluarga (Umar, 2003). Karena sistem perekonomian yang berlaku pada masyarakat purba adalah sistem barter, maka pekerjaan perempuan, walaupun masih dalam lingkup domestik, akan tetapi sebenarnya mengandung nilai ekonomi yang sangat tinggi. Ketika masyarakat berkembang menjadi masyarakat agraris dan kemudian menjadi masyarakat industri, keterlibatan perempuan pun sangat besar. Bahkan dalam masyarakat berladang di berbagai suku di dunia, perempuan banyak terlibat menjaga ternak dan mengelola ladang dengan baik dibanding laki-laki. Hal ini menunjukkan bahwa keterlibatan perempuan dalam meningkatkan ekonomi keluarga bukan merupakan hal yang baru (Dzuhayatin dan Siti, 2007).

Meskipun perempuan bekerja bukan merupakan fenomena yang baru, akan tetapi masalah perempuan bekerja tampaknya masih terus diperbincangkan sampai sekarang. Bagaimanapun, masyarakat masih memandang keluarga yang ideal adalah suami bekerja di luar rumah, dan istri mengerjakan pekerjaan rumah. Stereotip yang kuat di masyarakat adalah idealnya suami berperan sebagai pencari nafkah dan pemimpin yang penuh kasih, dan istri menjalankan fungsi pengasuhan anak. Hanya saja, seiring dengan perkembangan zaman, tentu saja peran-peran tersebut tidak semestinya dibakukan, terlebih kondisi ekonomi yang membuatnya tidak bisa menutup mata bahwa kadang-kadang istri pun dituntut untuk harus bekerja sebagai pencari nafkah (Indraswari dan Juni, 1991).

Anggapan masyarakat bahwa perempuan sebaiknya mengurusi di wilayah rumah tangga merupakan anggapan yang stereotipe bahwa jika perempuan bekerja di luar rumah mengakibatkan rumah tangga terganggu keharmonisannya. Meski akan ada dampak jika suami-istri bekerja di luar rumah, akan tetapi solusi yang diambil semestinya tidak membebankan istri dengan dua peran sekaligus (double burden), mengasuh anak dan mencari nafkah, akan tetapi suami pun harus bantu-membantu supaya tercapai rumah tangga yang harmonis (Rahniawati, 2001). 


\section{- Faktor-faktor yang menyebabkan diskriminasi}

Secara umum diskriminasi gender dalam sektor pekerjaan dilatarbelakangi oleh adanya keyakinan gender yang keliru di tengah-tengah masyarakat. Peran gender (gender role) sebagai bentuk ketentuan sosial diyakini sebagai sebuah kodrat sehingga menyebabkan ketimpangan sosial dan hal ini sangat merugikan posisi perempuan dalam berbagai komunitas sosial baik dalam pendidikan, sosial budaya, politik dan juga ekonomi(Dzuhayatin dan Siti, 2007). Di sektor pekerjaan, ketidakadilan dapat saja terjadi karena hal-hal sebagai berikut.

\section{Marginalisasi dalam Pekerjaan}

Marginalisasi secara umum dapat diartikan sebagai proses penyingkiran perempuan dalam pekerjaan. Sebagaimana dikutip oleh Saptari menurut Alison Scott, seorang ahli sosiologi Inggris melihat berbagai bentuk marginalisasi dalam empat bentuk yaitu: (1). Proses pengucilan, perempuan dikucilkan dari kerja upahan atau jenis kerja tertentu, (2) Proses pergeseran perempuan ke pinggiran (margins) dari pasar tenaga kerja, berupa kecenderungan bekerja pada jenis pekerjaan yang memiliki hidup yang tidak stabil, upahnya rendah, dinilai tidak atau kurang terampil, (3) Proses feminisasi atau segregasi, pemusatan perempuan pada jenis pekerjaan tertentu (feminisasi pekerjaan), atau pemisahan yang semata-mata dilakukan oleh perempuan saja atau laki-laki saja. (4) Proses ketimpangan ekonomi yang mulai meningkat yang merujuk di antaranya perbedaan upah (Fakih, 1999).

Proses marginalisasi terhadap perempuan dapat dilihat pada program pemerintah orde baru yang menyebabkan terpinggirnya perempuan ke tempat semula akibat diterapkannya teknologi canggih, misalnya, mengganti tenaga bagian linting rokok, pengepakan dan proses produksi dalam suatu perusahaan dengan mesin-mesin yang lebih praktis dan ekonomis, sementara pekerja di bidang ini yang mayoritas ditekuni perempuan memupus harapan mereka untuk tetap dapat bekerja dalam rangka mengangkat derajat ekonomi keluarga. Mesin-mesin potong padi menggantikan pekerjaan ani-ani yang biasanya ditekuni perempuan, menjadikan mereka kehilangan pekerjaan (Vitalaya, 1998). 
Marginalisasi ini merupakan proses pemiskinan perempuan terutama pada masyarakat lapisan bawah yang kesejahteraan keluarga mereka sangat memprihatinkan. Marginalisasi perempuan tidak saja terjadi di tempat pekerjaan akan tetapi juga dapat terjadi dalam rumah tangga, masyarakat, kultur, dan bahkan negara. Marginalisasi terhadap perempuan sudah terjadi dalam rumah tangga dalam bentuk diskriminasi atas anggota keluarga yang laki-laki dan perempuan (Yanggo dan Huzainah, 1997).

Marginalisasi dalam bidang pertanian juga tidak terelakkan. Sejak revolusi hijau diberlakukan di Indonesia, perempuan yang sebelumnya berdaulat atas praktik pertanian mulai dari pemilihan benih, menanam, menyiangi, membuat pupuk alami, memanen, sampai menumbuk padi -mulai tersingkir. Modernitas telah menyingkirkan perempuan dari kedaulatannya atas tanah dan pengelolaan lingkungan. Menyempitnya peran perempuan di sektor pertanian akhirnya mendorong kaum perempuan beralih ke sektor lainnya, seperti industri dan jasa (Vitalaya, 1998).

Menurut Irwan Abdullah (1990), ada dua hal yang berkaitan dengan ketimpangan gender dalam bentuk marginalisasi. Pertama, pekerjaan-pekerjaan marginal yang dikerjakan perempuan dapat dilihat sebagai akibat dari proses identifikasi perempuan terhadap apa-apa yang sesuai dengan sifat perempuan seperti yang sudah dikonstruksi secara sosial. Identifikasi ini merupakan proses pemaknaan diri dan hal-hal yang berkaitan dengan kehidupan perempuan sehingga berbagai faktor diperhatikan di dalamnya. Dalam perspektif semacam ini kemudian ketimpangan gender tidak lain merupakan pilihan perempuan, bukan pemaksaan terhadap perempuan. Kedua, berbagai proses telah mereproduksi sifat perempuan dan kenyataan tentang pekerjaan-pekerjaan yang sesuai dengan sifat keperempuanan tersebut. Tingkat absensi perempuan yang tinggi (karena perempuan membutuhkan cuti hamil) seringkali dijadikan alas an untuk tidak memilih tenaga kerja perempuan atau menempatkan perempuan dalam pekerjaan marginal.

Sebagai akibat yang ditimbulkan dari proses marginalisasi adalah meningkatnya kemiskinan dan langkanya kesempatan kerja bagi perempuan. Aida Vitayala Hubeis (1998) mengatakan bahwa menurut laporan BPS sampai pertengahan 1998, penduduk miskin telah berlipat ganda secara mencengangkan menjadi 79,4 juta orang atau sekitar 39,1 persen dari total 
201,5 juta rakyat Indonesia (dengan setengah darinya yaitu 101,3 juta adalah perempuan). Angka ini mengisyaratkan pertumbuhan kemiskinan absolut yang meningkat 251,33 persen dalam jangka waktu dua tahun (1996-1998). Distribusi penduduk miskin di perkotaan dan pedesaan masing-masing 227,354 dan 241,78 persen. Komposisi perempuan banding laki-laki adalah 60:40. Jadi, lebih banyak perempuan harus menjadi miskin sebagai akibat krisis ekonomi berkepanjangan dan situasi yang tidak lagi kondusif.

\section{Kedudukan Perempuan yang Subordinat dalam Sosial dan Budaya}

Peran gender dalam masyarakat ternyata juga dapat menyebabkan subordinasi terhadap perempuan terutama dalam pekerjaan. Anggapan bahwa perempuan itu irrasional atau emosional menjadikan perempuan tidak bisa tampil sebagai pemimpin, dan ini berakibat pada munculnya sikap yang menempatkan perempuan pada posisi yang kurang penting (Saptari dan Bridgett, 1997).

Subordinat dapat terjadi dalam segala bentuk yang berbeda dari tempat ke tempat dan dari waktu ke waktu. Di Jawa misalnya, dahulu ada anggapan bahwa perempuan tidak perlu sekolah tinggi-tinggi, toh akhirnya juga akan ke dapur. Dalam rumah tangga masih sering terdengar jika keuangan keluarga sangat terbata, dan harus mengambil keputusan untuk menyekolahkan anakanaknya, maka anak laki-laki akan mendapatkan prioritas utama. Praktik seperti itu sesungguhnya berangkat dari kesadaran gender yang tidak adil (Krisni dan Murti, 2005).

Demikian juga berkaitan dengan pekerjaan. Tempat-tempat kerja tertutup untuk perempuan dalam angkatan bersenjata atau kepolisian. Potensi perempuan sering dinilai secara tidak fair. Hal ini mengakibatkan perempuan sulit untuk menembus posisi strategis dalam komunitas yang berhubungan dengan pengambilan keputusan. Perempuan di sektor pertanian pedesaan, mayoritas di tingkat buruh tani. Perempuan di sektor industri perkotaan terutama terlibat sebagai buruh di industri tekstil, garmen, sepatu, kebutuhan rumah tangga, dan elektronik. Di sektor perdagangan, pada umumnya perempuan terlibat dalam perdagangan usaha kecil seperti berdagang sayur mayur di pasar tradisional (Patimah, 2003). 
Di sektor publik, masalah umum yang dihadapi perempuan dalam pekerjaan adalah kecenderungan perempuan terpinggirkan pada jenis-jenis pekerjaan yang upahnya rendah, kondisi kerja buruk, dan tidak memiliki keamanan kerja. Hal ini berlaku khusus bagi perempuan berpendidikan menengah ke bawah. Pekerjaan di kota adalah sebagai buruh pabrik, sedangkan di pedesaan adalah sebagai buruh tani. Hal yang perlu digarisbawahi di sini adalah bahwa kecenderungan perempuan terpinggirkan pada pekerjaan marginal tersebut tidak semata-mata disebabkan faktor pendidikan. Dari kalangan pengusaha sendiri, terdapat preferensi untuk mempekerjakan perempuan pada sektor tertentu dan jenis pekerjaan tertentu karena upah perempuan lebih rendah dari laki-laki (Vitalaya, 1998).

Kenyataan lain juga dapat diperlihatkan pada buruh perempuan di sektor informal yang merupakan tempat kerja tidak teratur dan terorganisir. Dalam keadaan ini, buruh perempuan miskin lebih sering mengalami eksploitasi ketimbang buruh laki-laki. Di sawah-sawah Asia Tenggara misalnya, perempuan mendapat upah sepertiga lebih rendah dibanding lakilaki untuk pekerjaan yang sama, menghadapi pelecehan seksual, bekerja terus selama hamil dan melahirkan, serta tidak memiliki jaminan keselamatan dan kesehatan.

Laporan Bank Dunia, Poverty and Gender in India, mencatat bahwa India merupakan salah satu dari sedikit negara Asia di mana andil pekerja perempuan dalam sektor formal menurun dalam dasawarsa terakhir ini, yang disertai dengan pertumbuhan hebat di sektor informal sebagai sumber utama pekerjaan kaum perempuan urban. Di antara rumah tangga urban miskin, hampir semua perempuan bekerja dalam pekerjaan yang berkisar dari usaha pengumpulan kain perca sampai kerja bangunan, hingga produksi industri rumah tangga. Semuanya dilakukan dalam kondisi yang menawarkan sedikit sekali keamanan kerja, khususnya jam kerja panjang, kecilnya peluang menambah penghasilan pribadi, dan kondisi kerja yang keras atau tidak sehat. Akan tetapi, upaya mengatur dan memperbaiki kondisi di sektor informal, jika tidak dilakukan dengan keterlibatan penuh perempuan yang bersangkutan, bisa berakibat buruk terhadap peluang yang dapat di raih perempuan. Bank Dunia berpandangan bahwa sekalipun dimungkinkan menegakkan peraturan perburuhan yang ada di semua sektor informal, namun tindakan ini memiliki pengaruh serupa seperti dalam sektor formal, yakni perubahan ke produksi 
padat modal, penciutan tenaga kerja, dan berpretensi mendapatkan tenaga kerja yang fleksibel dan berupah rendah (Mukherjee, 2002).

Sebuah penelitian tentang buruh perempuan pada industri sepatu di Tangerang juga mengalami kondisi yang sama, yakni biaya tenaga kerja (upah) buruh laki-laki adalah $10-15 \%$ dari total biaya produksi. Adapun bila mempekerjakan perempuan, biaya tenaga kerja dapat ditekan hingga 5-8\% dari total biaya produksi. Dalam kasus tersebut, prosentase buruh perempuan adalah $90 \%$ dari total buruh. Kasus lain dengan substansi sama, ditemukan di sektor pertanian pedesaan. Sebuah penelitian tentang buruh perempuan pada agro industri tembakau ekspor di Jember bahwa untuk pekerjaan di kebun tembakau, buruh perempuan mendapat upah Rp. 1.650,00 perhari sementara buruh laki-laki mendapat upah Rp. 1.850,00 perhari. Prosentase buruh perempuan pada kasus tembakau adalah $80 \%$. Paling tidak, di kedua kasus tersebut telah terjadi penggunaan tenaga kerja perempuan untuk sektorsektor produktif tertentu dan pemisahan kegiatan-kegiatan tertentu atas dasar jenis kelamin. Dua hal ini dapat dilihat juga melalui peningkatan atau penurunan rasio perempuan di setiap jabatan.

\section{Stereotipe terhadap Perempuan}

Stereotipe secara umum diartikan sebagai pelabelan atau penandaan terhadap suatu kelompok tertentu. Pada kenyataannya stereotipe selalu merugikan dan menimbulkan diskriminasi. Salah satu jenis stereotipe itu adalah yang bersumber dari pandangan gender. Banyak sekali ketidakadilan terhadap jenis kelamin tertentu, umumnya perempuan, yang bersumber dari penandaan (stereotype) yang dilekatkan pada mereka. Misalnya, penandaan yang berawal dari asumsi bahwa perempuan bersolek adalah dalam rangka memancing perhatian lawan jenisnya, maka setiap ada kasus kekerasan atau pelecehan seksual selalu dikaitkan dengan stereotipe ini. Bahkan jika ada pemerkosaan yang dialami oleh perempuan, masyarakat berkecenderungan menyalahkan korbannya. Masyarakat memiliki anggapan bahwa tugas utama kaum perempuan adalah melayani suami. Stereotipe ini berakibat wajar sekali jika pendidikan kaum perempuan dinomorduakan (Rahniawati, 2001).

Demikian pula perempuan adalah jenis manusia yang lemah fisik maupun intektualnya sehingga tidak layak untuk menjadi pemimpin. Perempuan sarat dengan keterbatasan, tidak sebagaimana laki-laki. Aktivitas laki-laki lebih leluasa, bebas, lebih berkualitas, dan produktif. Misalnya laki- 
laki dianggap sebagai pencari nafkah utama, perempuan hanya dinilai sebagai suplemen, karena itu perempuan dalam sistem penggajian atau upah boleh dibayar lebih rendah dari laki-laki. Keterpurukan ini semakin parah dengan mencari legitimasi agama yang disalahtafsirkan (Rahayu, 2005).

Diskriminasi upah yang terjadi secara eksplisit maupun implisit, seringkali memanipulasi ideologi gender sebagai pembenaran. Ideologi gender merupakan aturan, nilai, stereotipe yang mengatur hubungan antara perempuan dan laki-laki terlebih dahulu melalui pembentukan identitas feminin dan maskulin. Karena tugas utama perempuan adalah di sektor domestik, maka pada saat ia masuk ke sektor publik sah-sah saja untuk memberikan upah lebih rendah karena pekerjaan di sektor publik hanya sebagai sampingan untuk membantu suami (Vitalaya, 1998).

Beberapa alasan yang menyebabkan rendahnya angka partisipasi perempuan dalam kerja adalah, Pertama, menyangkut persepsi mengenai kerja (yang dilakukan) perempuan berkaitan dengan peran domestik perempuan, kedua, berkaitan dengan persepsi tersebut adalah perangkat pengukuran, penentuan, atau pendefinisian pekerjaan perempuan, dan yang ketiga adalah sifat musiman, paruh waktu, dan informal dari kebanyakan pekerjaan perempuan. Gambaran tersebut memperlihatkan bahwa hambatan mobilitas yang mengakibatkan lemahnya informasi pasar, layanan usaha, keterbatasan mengakses jaringan bisnis, serta tidak memiliki agunan menjadi disinsentif dan kendala bagi perempuan pengusaha untuk menekuni dunia usaha, meski sebenarnya perempuan pengusaha memiliki kekuatan dan potensi khusus, tetapi secara nyata lebih berhati-hati dan realistis daripada laki-laki (Rahniawati, 2001).

Peran domestik menurut anggapan orang hanya pantas dilakukan oleh perempuan. Keadaan tersebut menyebabkan posisi perempuan sarat dengan pekerjaan yang beragam, dalam waktu yang tidak terbatas, dan dengan beban yang cukup berat. Misalnya, memasak, mencuci, menyeterika, menjaga kebersihan dan kerapian rumah, membimbing anak-anak belajar, dan sebagainya (Umar, 2003).

Pekerjaan domestik tersebut dilakukan bersama-sama dengan fungsi reproduksi, haid, hamil, melahirkan, dan menyusui. Adapun laki-laki dengan peran publiknya menurut kebiasaan masyarakat, tidak bertanggung jawab 
terhadap beban kerja domestik tersebut, karena hanya layak dikerjakan oleh perempuan (Umar, 2003).

Peran ganda perempuan dalam pekerjaan, baik di ranah publik maupun domestik menyebabkan hasil kerja perempuan dianggap pekerjaan yang rendah dan tidak memperoleh imbalan materiil yang seimbang dengan beban pekerjaannya. Realitas ini memperkuat ketidakadilan gender yang telah melekat dalam kultur masyarakat. Lebih-lebih lagi jika perempuan harus bekerja pada peran publik untuk meningkatkan penghasilan ekonomi keluarga, maka semakin berat beban yang ditanggung perempuan. Apalagi jika lingkungannya, baik suami atau anggota keluarga lainnya tidak ikut membantu tugas-tugas domestik, karena secara kultural dianggap bukan kewajiban laki-laki untuk melaksanakan pekerjaan domestik tersebut (Saptari, Ratna dan Brigett Holzner.1997).

Bagi kelas menengah dan golongan kaya, beban kerja tersebut kemudian dilimpahkan kepada pembantu rumah tangga, di mana mereka adalah korban bias gender dalam masyarakat. Mereka bekerja lebih lama dan berat, tanpa perlindungan dan kebijakan Negara (Cleves dan Julia, 2002).

Dari gambaran persoalan di atas, dapat dilihat telah terjadi pelebaran ketimpangan ekonomi antara laki-laki dan perempuan yang ditandai oleh perbedaan upah serta ketidaksamaan akses keuntungan dan fasilitas kerja, termasuk akses terhadap program-program pelatihan untuk pengembangan kerja, akses perlindungan, akses kredit atau permodalan, akses hukum, serta kesehatan.

\section{Tingkat Pendidikan Perempuan Rendah}

Kecenderungannya adalah semakin tinggi jenjang pendidikan, maka makin meningkat kesenjangan gendernya, proporsi laki-laki yang bersekolah semakin lebih besar dibandingkan dengan proporsi perempuan yang bersekolah. Kesenjangan ini disebabkan oleh berbagai hal di antaranya adalah pertimbangan prioritas berdasarkan nilai ekonomi anak, bahwa nilai ekonomi anak laki-laki lebih mahal dibandingkan dengan nilai ekonomi anak perempuan (Krisni dan Murti, 2005).

Gejala pemisahan gender (gender segregation) masih banyak tampak dalam pemilahan jurusan (SMK-Ekonomi untuk perempuan dan SMK-Teknik Industri untuk laki-laki) yang berakibat pada diskriminasi gender pada institusiinstitusi pekerjaan. 
Di beberapa tempat di Indonesia, sebagai akibat dari rendahnya pendidikan mereka, banyak mempekerjakan perempuan sebagai TKW. Banyak di antara mereka yang hanya berbicara dalam bahasa daerah saja dan bukan bahasa Indonesia, sebagai bahasa nasional yang sering diajarkan di sekolah (Indraswari dan Juni, 1991).

Dari gambaran tersebut, dapat dijelaskan bahwa pendidikan yang rendah merupakan faktor yang turut menyebabkan diskriminasi dalam pekerjaan. Rendahnya pendidikan dan keterampilan mempersulit perempuan yang masih gadis untuk mencari pekerjaan lain agar dapat menghidupi dirinya dan keluarganya.

Banyak dari pekerja-pekerja yang hanya membutuhkan sedikit keterampilan ini menuntut migrasi ke kota besar atau ke luar negeri, di mana perempuan menjadi target para pelaku trafficking dan pihak lain yang berniat mengeksploitasi mereka. Dengan rendahnya tingkat pendidikan serta kurangnya keterampilan kerja yang memadai, para perempuan yang masih gadis hanya mencari pekerjaan di sektor informal. Pekerjaan di sektor informal bagi perempuan yang tidak berpendidikan biasanya seperti pramuwisma, atau penjual minuman di kaki lima, pembantu rumah tangga, penjaja makanan di terminal dan stasiun, yang tidak memperoleh perlindungan dari pemerintah dan tenaga kerja melalui serikat buruh atau majikan (Faqihuddin dkk, 2006).

Pendidikan yang minim dan tingkat melek huruf yang rendah semakin menyulitkan perempuan untuk mencari pekerjaan. Jika akhirnya mendapat pekerjaan, diposisikan pada bagian yang tidak memerlukan keterampilan misalnya buruh, tenaga suruhan, yang memiliki pengupahan yang sangat rendah, tidak mendapat perlindungan hukum dan juga kesehatan. Mereka tidak tahu bagaimana mengakses sumber daya yang tersedia, karena tidak dapat membaca dan menulis untuk mencari bantuan hukum ataupun rumah singgah jika majikan mereka bertindak eksploitatif atau melakukan kekerasan, baik fisik, psikis, maupun seksual (Faqihuddin dkk, 2006.

\section{PENUTUP}

Berdasarkan uraian yang sudah dipaparkan diatas, maka dapat ditarik kesimpulan bahwa dalam lintasan sejarah pada awalnya pembagian kerja, baik secara biologi maupun gender antara laki-laki dan perempuan dianggap sama- 
sama memiliki nilai dan keseimbangan. Perubahan tersebut muncul karena adanya penggeneralisasian perekonomian uang yang diberlakukan, di samping karena budaya patriarkhi sehingga menimbulkan diskriminasi dalam pekerjaan. Kondisi ini diperparah dengan sistem yang dipakai dalam masyarakat modern dalam pekerjaan. Akibat dari modernitas, perempuan mengalami marginalisasi dalam sektor pekerjaan yang berakibat pada kecenderungan perempuan untuk melakukan pekerjaan informal yang kurang memberikan perlindungan hukum dan upah yang rendah. Di samping itu, faktor subordinat perempuan dalam sosial maupun kultural, stereotipe terhadap perempuan serta pendidikan yang rendah juga turut mempengaruhi diskriminasi perempuan dalam pekerjaan.

\section{DAFTAR PUSTAKA}

Abdullah. Irwan. 1990. "Wanita ke Pasar: Studi Tentang Perubahan Sosial Ekonomi Pedesaan", dalam Jurnal Populasi. Vol.I, No. I.

Amar, S., 2017, Perjuangan Gender Dalam Kajian Sejarah Wanita Indonesia Pada Abad Xix, Fajar Historia, 1(2): 115-119.

Andrey Shastri,"Gender Inequality and Women Discrimination", IOSR Journal And Social Science, Vol. 19 No.11, 2014, hlm. 27-30

Asgar Ali Enginer, Hak-Hak perempuan dalam Islam terj. Farid Wajidi dan Cici Farkha Assegaf, (Yoyakarta Lembaga study Pengembangan Perempuan dan Anak 1994)

Ayu, M, L., Novia. P A., 2020, The Education For Gender Equality And Human Rights In Indonesia: Contemporary Issues And Controversial Problems. The Indonesian Journal of International Clinical Legal Education, 2(1), 73-84

Badan Pusat Statistik Tahun 2000.

Badan Pusat Statistik: SP 1990. Supas 1995. Statistik Kesejahteraan Rakyat 2001-2004.

Cleves Mosse, Julia. 2002. Gender dan Pembangunan. terj. Hartian Silawati. Yogyakarta: Pustaka Pelajar.

Darahim, Andarus. 2003. Kendala Upaya Pemberdayaan Perempuan. Jakarta: Yayasan Melati.

Dzuhayatin, Siti Ruhaini. 2007. "Gender dalam Tatanan Internasional dan Nasional" dalam Din Wakhid (Ed.). Agama Politik Global dan Hak-hak Perempuan.

Fakih, Mansour. 1999. Analisis Gender dan Transformasi Sosial. Yogyakarta: Pustaka Pelajar. 
Faqihuddin. dkk. 2006. Fiqh Anti Traffiking, Jawaban Atas Berbagai Kasus Kejahatan Perdagangan Manusia dalam Perspektif Hukum Islam. Cirebon: Fahmina Institut.

Fibrianto, A. S., \& Bakhri, S. 2018. Pelaksanaan Aktivitas Ekstrakurikuler Paskibra (Pasukan Pengibar Bendera) Dalam Pembentukkan Karakter, Moral Dan Sikap Nasionalisme Siswa Sma Negeri 3 Surakarta. Jurnal Moral Kemasyarakatan, 2(2), $1-19$.

Hungu. 2007. Demografi Kesehatan Indonesia. Jakarta: Penerbit Grasindo.

Indraswari dan Juni Thamrin. 1991. "Potret Kerja Buruh Perempuan, Tinjauan pada Agro Industri Tembakau Ekspor di Jember”. dalam Jurnal Akatiga. Juni 1991.

Kementerian Pemberayaan Perempuan dan Perlindungan anak Republik Indonesia, 2018, Kesetaraan Gender : Perlu Sinergi Antar Kementerian / Lembaga, Pemerintah Daerah, Dan Masyarakat, https://www.kemenpppa.go.id/index.php/page/read/31/1667/kesetaraan-genderperlu-sinergi-antar-kementerian-lembaga-pemerintah-daerah-dan-masyarakat , diakses pada 27 April 2021.

Mukherjee, Nilanjana. 2002. Masyarakat, Kemiskinan, dan Mata Pencaharian: Mata Rantai Pengurangan Kemiskinan di Indonesia. Kerjasama Departemen Bantuan Luar Negeri dan Kantor Perwakilan Bank Dunia di Jakarta.

Murata, Sachiko. 1999. The Tao of Islam. terj. Rahmani Astuti dan NS Nasrullah. Bandung: Mizan.

Murti M.S., Krisni. 2005. dalam Jurnal Perempuan No 44. Jakarta: Yayasan Jurnal Perempuan.

Patimah. 2003. "Dinamika Ekonomi Perempuan dalam Industri Kecil dan Menengah" dalam Jurnal Equalita. Vol. 3. No. 2. Juni 2003.

Rahayu. 2015. Hukum Hak Asasi Manusia. Semarang : Badan Penerbit Universitas Diponegoro. HIm 153-156.

Rahima, Swara. Makalah. tidak diterbitkan.

Rahniawati, N., 2001, Isu Kesetaraan Laki-Laki Dan Perempuan (Bias Gender), MIMBAR, 17(3): 273-285.

Rancangan Undang-Undang Negara Republik Indonesia Tentang Kesetaraan dan Keadilan Gender Tahun 2012.

Saptari, Ratna dan Brigett Holzner.1997. Perempuan Kerja dan Perubahan Sosial, Sebuah Pengantar Studi Perempuan. Jakarta: Pustaka Utama Grafiti.

Umar, Nasaruddin. 2003. Argumen Kesetaraan Gender dalam Perspektif alQur'an. Jakarta: Paramadina.

Undang-Undang Negara Republik Indonesia Nomor 1 Tahun 1974 Tentang Perkawinan. 
Undang-Undang Nomor 7 Tahun 1984 tentang Pengesahan Konvensi Mengenai Penghapusan Segala Bentuk Diskriminasi Terhadap Wanita

Undang-Undang Negara Republik Indonesia Nomor 7 Tahun 1984 Tentang Pengesahan Konvensi Mengenai Penghapusan Segala Bentuk Diskriminasi Terhadap Wanita.

Vitalaya, Aida. 1998. "Gender dalam Pembangunan sosial Ekonomi". Makalah.

Yanggo Tahido, Huzaimah. 1997. "Perlindungan Islam Terhadap Hak Ekonomi Perempuan" dalam Dadang S. Anshori (Ed.). Membincang Feminisme. Refleksi Muslimah atas Peran Sosial Kaum Perempuan. Bandung: Pustaka Hidayah.

Syahruddin Nawi. 2017. Metode Penelitian Hukum Normative Versus Empiris Edisi 5. Makassar: PT. Umitoha. 